\title{
Do the Standards of the National Commission for Academic Accreditation \& Assessment (NCAAA) Lead to Organization Excellence
}

\author{
Ghadah Alsaleh, (PhD) \\ Jubail University College, Saudi Arabia
}

doi: 10.19044/esj.2016.v12n34p103 URL:http://dx.doi.org/10.19044/esj.2016.v12n34p103

\begin{abstract}
One way to meet the challenges in creating a high preforming educational institution is the approach of organization excellence. The National Commission for Assessment and Academic Accreditation (NCAAA) was established under the supervision of the Higher Education Council and Ministry of Education in Saudi Arabia to assure the quality standards are applied. This research aims to examine the NCAAA standards based on well-known models for organization excellence that has been used in the education sector. Results show that the NCAAA should focus on some specific areas to assure that excellence of educational is instituted. These areas include: leadership, strategic planning and partnership.
\end{abstract}

Keywords: Higher education; MBNQA; NCAAA; organization excellency

\section{Introduction}

In the competitive business world and as economic growth, educational institutions are challenged to provide high quality programs. "Improve or perish" is the motto that the business world should adopt to stay competitive in the changing and growing global market (Karapetrovic and Willborn, 2001). One of the very popular and positively accepted tools to achieve continual improvement is implementing the principles of organization excellence. Most recently, the Centre for Organizational Excellence Research reported research findings on the impact and value of organizational excellence in Asia (India, Japan, Singapore, Taiwan, Thailand). The findings show that organizational excellence had a major impact on organizations' long-term competitiveness, performance and sustainability (Mann, 2011). Indeed, organizational excellence principles endorse applying best practices and tools that allow adopting the quality strategy of benchmarking of best practices, self-assessment and continuous improvement (Alpana \& Prem, 2016). Prizes in different countries such as 
the Baldridge Award and the European Quality Award have been established for institutions that attain high performance levels in specific dimensions to suggest roadmaps to excellence.

In higher education, excellence has been discussed in different researches (Ho and Wearn, 1996; Badri and Abdulla, 2004; Hides et al., 2004; Osseo-Assare et al., 2005; Badri et al., 2006; Sadiq-Sohail and Shaikh, 2004; Calvo-Mora et al., 2006). An excellent higher education institution is definitely proactive, has a shared vision, aims at continuous improvement, and introduces trust and respect among the staff that is committed, is reflective and monitors quality (Lomas, 2004). Loukas adds that an excellent university is identified by superior performance not only in management, but also in teaching, research and external engagement processes and quality must characterize every policy, procedure or process in the educational pillar of universities (Loukas, 2007).

In the educational sector in Saudi Arabia, there is an increasing demand to achieve Quality. Students, employers, parents and members of the community should be able to have complete confidence that skills learned by students, research conducted by faculty, and services provided by universities are equivalent to good international practice. For that, the Higher Council of Education in Saudi Arabia established The National Commission for Academic Accreditation \& Assessment in 2004 with responsibility to establish standards and accredit institutions and programs in post-secondary education. Accreditation of an institution or a program will give public recognition that these standards have been achieved. The aim is to promote the Saudi universities' qualifications and improve their reputations.

Using the literature, this paper critically analyses and examines the quality standards provided by The National Commission for Assessment and Academic Accreditation (NCAAA) based on well-known models for organization excellence: Malcolm Baldrige National Quality Award of Performance Excellence (MBNQA) and European Foundation for Quality Management (EFQM) since these models have been used in evaluating the excellency of education sector.

\section{Organization Excellence}

Scholars have defined organization excellence from different perspectives. The literal meaning of excellence is "Quality of highest order" (Sharma and Talwar, 2007). Grote has defined it as the ability of organizations to provide development opportunities, and to create conditions that stimulate, correct and face performance problems effectively (Grote, 2002). The excellence organization is distinguished by consistently excelling in the performance of its functions, and having good relations with 
customers and clients, it should identify the performance of its competitors, strengths and weaknesses, and the circumstances surrounding its environment (Gilgeous \& Gilgeous, 1999). In addition, excellence is a framework that offers a systemic view, asks for high engagement of human resources, enables self-improvement and thus it contributes to continuous change through quality monitoring at each stage and every process of the organization (Loukas, 2007).

Definitions of organization excellence focused on the importance of leadership, strategic planning, and customer's satisfaction. Grant clarifies that there are several determinants to achieve organization excellence; such as the presence of visionary leadership, focusing on the future through strategic planning, activating the role of knowledge and adoption of organizational learning (Grant, 2000).

Still, as organization research progressed, various management theories and models have evolved and been practiced to attain excellence (Alpana \& Prem, 2016). A number of business models are available in literature for evaluating organizational excellence that consider certain sets of principles, criteria and approaches to facilitate achievement of best results in long term, and therefore provide support in sustainable development (Sampaio et al., 2012).

The most widespread reference models for framing excellence in organizations and for self-assessment and improvement are the Malcolm Baldrige National Quality Award in the USA, the Deming Prize in Japan, the European Excellence Award based on the EFQM model, the Singapore Quality Award and the Australian Business Excellence Award (Khoo \& Tan, 2002). The Malcolm Baldrige National Quality Award of Performance Excellence (MBNQA) and the European Foundation for Quality Management Excellence Model (EFQM) were established to give prizes for institutions that attain high performance level in specific dimensions and have been used in education to empower educational institutions to reach their goals and improve the results.

\section{Malcolm Baldrige National Quality Award of Performance Excellence (MBNQA)}

The Malcolm Baldrige National Quality Award of Performance Excellence was established by the U.S. Congress in 1987 to raise awareness of quality management and recognize U.S. companies that have implemented successful quality management systems. The prize can be given in seven different categories and education is one of them (NIST, 2005).

Study in the USA evaluated the attitudes and perceptions of senior leaders towards the Baldrige Award and its Criteria and revealed very broad, positive recognition among leaders in each of the award eligible sectors: 
manufacturing, service, education, health care, and small business. In addition, more than 70 percent of leaders surveyed at Fortune 1,000 companies said they are likely to use the Baldrige criteria (Booz Allen Hamilton, 2003).

The Criteria of evaluation in MBNQA are built based on a set of interrelated core values and concepts found in high performing organizations. These core values and concepts are gathered in seven linked categories (Figure 1).

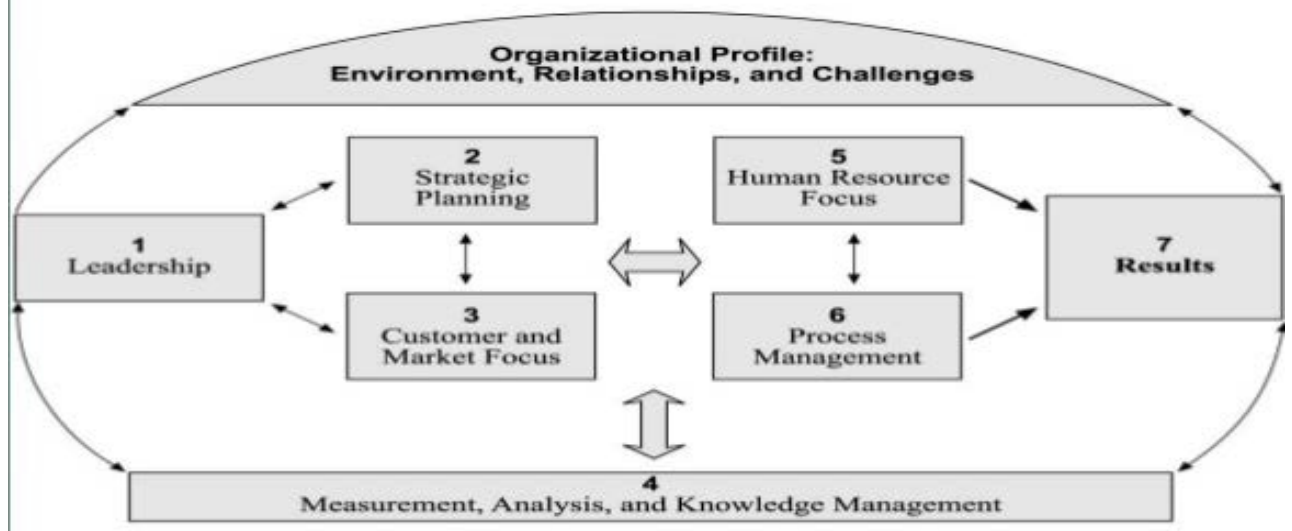

Figure 5 Baldrige Criteria for performance excellence

Each category is subdivided into a specific number of items, with each item focusing on a set of major performance requirements. Points are allocated to each item, using a scoring guideline, based on the level of evidence of actual performance (Blazey, 2001).

The criteria of leadership focuses on examining the actions of senior leaders and how the governance system guides and sustains the organization. It is concerned with ethical, legal and community responsibilities. The criteria of strategic planning examines how strategic directions and action plans were developed and how the progress will be measured. It stresses that the organization's long-term success and competitive environment are key strategic issues that need to be integral parts of overall planning. The criteria of customer and market focus examines how the organization determines requirements and expectations of customers and markets. It examines how the organization builds relationships with customers; and acquires, satisfies, and retains them. The criteria of measurement, analysis, and knowledge management focuses on the management, use, analysis, quality and security of data, information, hardware and software to support key organization processes normally and in the event of emergency. It is the brain center for the alignment of all operations and strategic objectives. The criteria of human resources addresses key workforce practices that direct toward creating and maintaining a high performance environment and towards 
engaging, managing, and developing the workforce. It is concerned about addressing the core competencies and accomplishing the action plans. The criteria of process management examines how organization manages, designs and improves key production/delivery and support processes. The criteria of results provides a system focus that encompasses all results necessary to sustain the organizations success. It looks into the results in key business areas which are: customer satisfaction, financial and marketplace performance, workforce, product/service, and operational effectiveness, and leadership. It also examines how the organization performs relative to competitors.

\section{European Foundation for Quality Management (EFQM)}

The success of the Baldrige Model in the US encouraged 14 representatives of European multi-national companies such as British Telecom, Volkswagen and Philips to initiate the European Foundation for Quality Management (EFQM) in 1988 (European Foundation for Quality Management, 2000). The Model is regularly reviewed and refined where the last update was published in 2013.

The EFQM Model provides a framework allowing organizations to determine their current "level of excellence" and where they need to focus improvement efforts. Moreover, the EFQM Model helps to ensure that business decisions incorporate the needs of all stakeholders and are aligned with the organization's objectives. The EFQM Excellence Model takes into account the cause and effect relationships between what the organization does, the Enablers, and the Results it achieves (figure2).

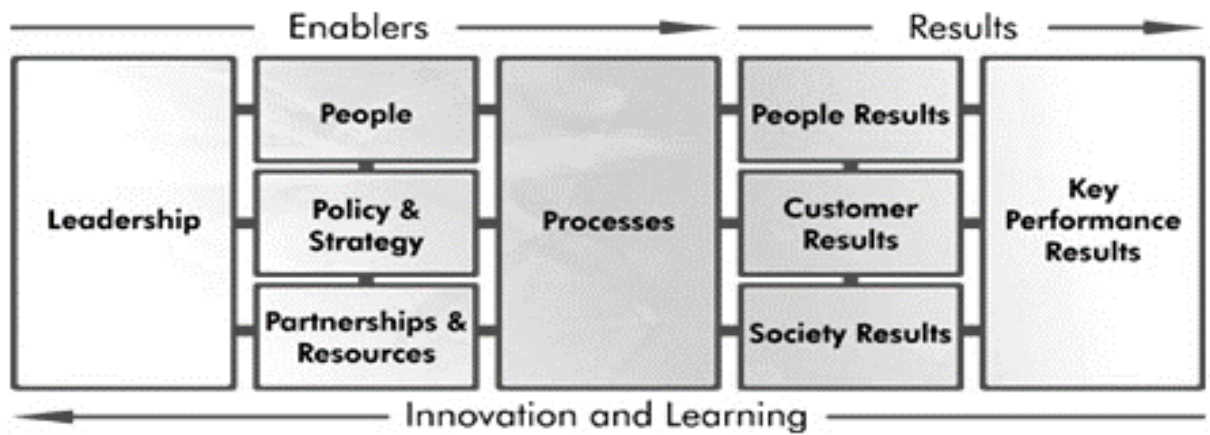

Figure 6 European Foundation for Quality Management Criteria for performance excellence

In Europe, a study found that when the principles of the EFQM Excellence model have been implemented effectively, performance improves in both short- and long-time periods (Boulter et al., 2005). According to Hillman (1994), "EFQM provides a tried and tested framework, an accepted basis for evaluation and a means to facilitate comparisons both internally and 
externally.” (p. 29). Watson explains that the EFQM Model provided a true service-focused quality system with an inbuilt mechanism to accomplish continued organizational improvement (Watson, 2000). Mønsted and Føns (2002) note that one of the biggest advantages of using the model of excellence EFQM is in implementation of the self-assessment.

The EFQM Excellence Model is a generic model for quality management, which is used in all types of organizations, regardless of sector, size, structure or maturity. The essence of the approach is a model with nine criteria. The nine criteria are: leadership, people, policy and strategy, partnership and resources, process, people results, customer results, society results and key performance results. The nine criteria are grouped into Enabler and Result. There are five Enablers that include: leadership, people, policy and strategy, partnership and resources and process. Moreover, there are four Result areas: people, customer, society and key performance results. These are the results an organization achieves that are in line with their strategic goals. In all four Results areas, excellent organizations have to develop a set of key performance indicators and related outcomes to determine the successful deployment of their strategy which is based on the needs and expectations of the relevant stakeholder groups.

Based on EFQM, to achieve sustained success, an organization needs strong leadership and clear strategic direction. Organization needs to develop and improve people, partnerships and processes to deliver valueadding products and services to customers. If the right approaches are effectively implemented, organization will achieve the targeted results.

\section{National Commission for Academic Accreditation \& Assessment (NCAAA)}

The National Commission for Academic Accreditation \& Assessment was established in 2004 by the Higher Council of Education in Saudi Arabia with responsibility to establish standards and accredit institutions and programs in post-secondary education. The standards apply to all public and private universities and colleges, including those responsible to the Ministry of Higher Education and to any that are established or regulated by other ministries or agencies.

The Commission's responsibilities relate to quality issues, which include the resources available, processes followed, the quality of services provided and the quality of students learning. The Commission has established required standards in eleven broad areas of activity, and has developed a national qualifications framework that specifies generic standards of learning outcomes for each level of qualifications. It expects that institutions establish internal quality assurance systems that ensure high levels of quality in all of these eleven areas. Standards include: Mission 
Goals and Objectives, Governance and Administration, Management of Quality Assurance and Improvement, Learning and Teaching, Student Administration and Support Services, Learning Resources, Facilities and Equipment, Financial Planning and Management, Employment Processes, Research and Institutional Relationships with the Community.

The focus on mission, goals and objective standards is to clearly and appropriately define the institution's principal purposes and priorities and be influential in guiding planning and action. Governance and administration standard focuses on providing effective leadership in the interests of the institution as a whole and its clients. Planning and management must occur within a framework of sound policies and regulations to ensure accountability. Management of Program Quality Assurance standard shows that quality assurance processes must involve all sections of the institution and be effectively integrated into normal planning and administrative processes. Learning and Teaching standard requires an effective system to ensure that all programs meet high standards of learning and teaching through initial approvals, monitoring of performance, and provision of institution-wide support services. In the Student Administration and Support Services standard, admission processes, students' rights and responsibilities must be clearly defined and understood. Learning Resources standard includes libraries and provisions for access to electronic and other reference material which must be planned to meet the university requirements. In the Facilities and Equipment standard, adequate facilities and equipment must be available for the teaching and learning requirements. In Financial Planning and Management standard, financial resources must be sufficient for the effective delivery of the programs. Budgetary processes should allow for long term planning and flexibility must be provided for effective management and responses to unexpected events. In the Employment Processes standard, staff must have the qualifications for the job and must go through the orientation, evaluation and development process. In Research standard, the focus is to develop a research strategy that is consistent with the nature and mission of the institution. Finally, Relationships with the Community standard assures significant and appropriate contributions to the community.

\section{Aligning NCAAA to Organization Excellence Models}

There are many similarities between NCAAA and excellence models. However, NCAAA lacks the focus on some important elements such as leadership, strategic planning, results, continuous improvements and partnership. Indeed, leadership is a main element in the EFQM and Baldrige models. Leadership is highly important since leaders are responsible for many vital activities related to excellence such as deploying excellence 
culture in organizations, formulating a future vision, making partnerships and applying governance. Also, Leadership is crucial in initiating and implementing the change needed to achieve organizational excellence (Vora, 2013).

Furthermore, strategic planning is a main element at Baldrige. The importance of strategic planning is to set strategic directions for organizations and developing long and short-term plans. In EFQM, strategic planning appears under the strategy and policy component which is responsible for determining future needs and stakeholder ambitions. On the other hand, the mission and goals are main elements in NCAAA but strategic planning is a sub-component under governance and administration.

Moreover, partnership is considered a very critical element. EFQM points out partnership by emphasizing the importance of funders and strategic partners. However, the NCAAA does not give the partnership high attention, instead focuses on the value of developing relations with the community in general.

Continuous learning, improving and innovation appear in the excellence models to emphasize the importance of learning from experience and feedback to improve and innovate in the work. However, the NCAAA did not mention this criteria as a main standard.

On the other hand, some standards in NCAAA are related to each other and could be grouped under one category. Management of Quality Assurance and Improvement, Learning and Teaching, Student Administration and Support Services, and Financial Planning and Management standards could be grouped to one category called (Process). In addition, Learning Resources and Facilities and Equipment could be grouped to one category called (Resources).

It is important to note that guidance for integration at the operational/process level should be provided to assure the success of the holistic perspective of any organizational model (Dahlgaard et al., 2013). For that, the NCAAA should include guidance to the applying process and provide suggestions as to the best practices.

Based on all the above, the NCAAA can be improved to help universities in achieving the excellence and being on the standards of international universities. Suggested improvements are grouped in the proposed model for the NCAAA as in figure 3. 


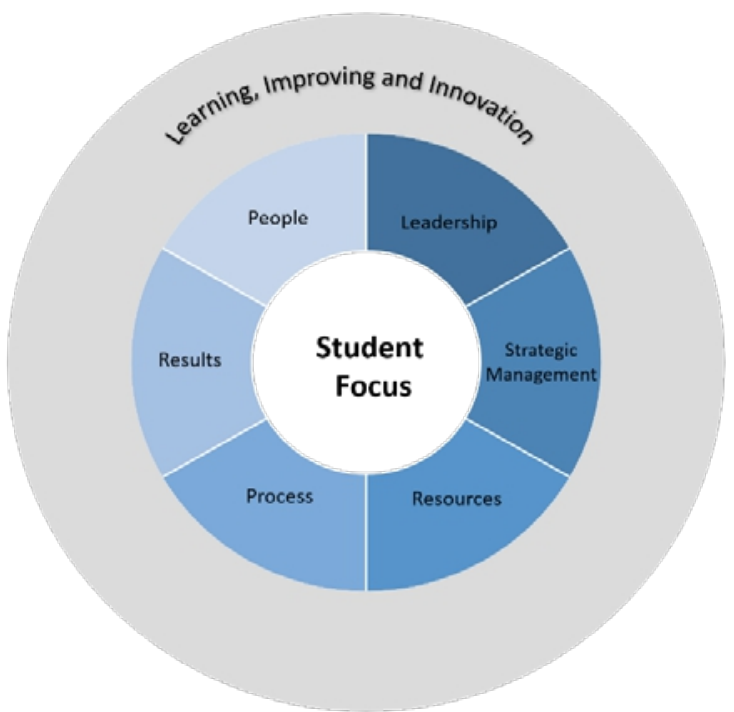

Figure 7 The Proposed Model for performance excellence

\section{Conclusion}

To assure the quality of education in Saudi Arabia, The National Commission for Assessment and Academic Accreditation (NCAAA) was established under the supervision of the Higher Education Council and Ministry of Education in Saudi Arabia. However, until 2016, only 14 universities out of 39 in Saudi Arabia have been accredited by the NCAAA (NIST, 2016).

For that, the NCAAA should benefit from the most common international performance excellence models to improve the national standard. Improving the NCAAA standards can be achieved by focusing on leadership, strategic planning, continuous learning and improvements and partnership. Since the quality establishes a basic prerequisite to pursue excellence in a higher education institution (Loukas, 2007), the NCAAA should focus on creating a culture of excellence in universities by going behind the quality.

\section{References:}

1. Higher Education in Saudi Arabia, Summary Report, 1428 AH. http://www.ncaaa.org.sa/

2. Alpana Agarwal , Prem Vrat , (2016) "A bio-inspired model of organizational excellence", Journal of Advances in Management Research, Vol. 13 Iss: 2, pp.130 - 153.

3. Badri, M. and Abdulla, M. (2004), "Awards of excellence in institutions of higher education: an AHP approach", International Journal of Educational Management, Vol. 18 No. 4, pp. 224-42. 
4. Badri, M.A., Selim, H., Alshare, K., Grandon, E., Younis, H. and Abdulla, M. (2006), "The Baldridge education criteria for performance excellence framework: empirical test and validation”, International Journal of Quality \& Reliability Management, Vol. 23 No. 9, pp. 1118-57.

5. Blazey, M.L. (2001), Insights to Performance Excellence: An Inside Look at the 2001 BaldrigeAward Criteria, ASQ Press, Milwaukee, WI.

6. Booz Allen Hamilton (2003), Assessment of Leadership Attitudes about the Baldrige National Quality Program, Malcolm Baldrige National Quality Program, National Institute of Standards and Technology, Gaithersburg, MD.

7. Boulter, F., Bendell, T., Abas, H., Dahlgaard, J. and Singhal, V. (2005), Report on EFQM and BQF Funded Study into the Impact of the Effective Importance of Organizational Excellence Strategies on Key Performance Results, The Centre of Quality Excellence, University of Leicester, Leicester.

8. Calvo-Mora, A., Leal, A. and Roldan, J. (2006), "Using enablers of the EFQM model to manage institutions of higher education”, Quality Assurance in Education, Vol. 14 No. 2, pp. 99-122.

9. Dahlgaard, J.J., Chen, C.K., Jang, J.Y., Banegas, L.A. and Dahlgaard-Park, S.M. (2013), “Business excellence models: limitations, reflections and further development”, Total Quality Management \& Business Excellence, Vol. 24 Nos 5-6, pp. 1-25.

10. European Foundation for Quality Management (2000a), History of the EFQM, [accessed 12

11. Gilgeous, V. (1997). Operations and Management Change. London: Pitman.

12. Gilgeous, V., \& Gilgeous, M. (1999). A framework for manufacturing excellence. Integrated Manufacturing Systems, 10(1), 33-44.

13. Grant, R. (2000). Contemporary Strategy Analysis. UK: Oxford.

14. Grote, D. (2002). The Performance Appraisal Question and Answer Book Survival Guide For Managers. United States of America.

15. Hides, M., Davies, J. and Jackson, S. (2004), "Implementation of EFQM excellence model self-assessment in the UK higher education sector-lessons learned from other sectors”, The TQM Magazine, Vol. 16 No. 3, pp. 194-201.

16. Hillman, G. P. (1994). Making self-assessment successful. The TQM Magazine, 6(3), 29-31. 
17. Ho, S. and Wearn, K. (1996), “A higher education TQM excellence model: HETQMEX”, Quality Assurance in Education, Vol. 4 No. 2, pp. 35-42.

18. June 2000] at URL:www.efqm.org/history/htm.

19. K. Vora, M. (2013). Business excellence through sustainable change management. The TQM Journal, 25(6), 625-640.

20. Karapetrovic, S. \& Wilborn, W. (2001). "Audit and self-assessment in quality management: comparison and compatibility”, Managerial Auditing Journal, 16(6), 366-377, DOI: 10.1108/02686900110395505.

21. Khoo, H.H. and Tan, K.C. (2002), "Nine approaches to organizational excellence”, Journal of Organizational Excellence, Vol. 22 No. 1, pp. 53-65.

22. Lomas, L., (2004), "Embedding quality: the challenges for higher education”, Quality Assurance in Education, Vol.12, No.4, pp.157165.

23. Loukas N. Anninos, (2007) "The archetype of excellence in universities and TQM", Journal of Management History, Vol. 13 Iss: 4, pp.307 - 32.

24. Mann, R.D.M.T. (2011), "Deployment of business excellence in Asia: an exploratory study”, International Journal of Quality \& Reliability Management, Vol. 28 No. 6, pp. 604-627.

25. Mønsted, M. \& Føns, T. (2002). A comparative assessment of the EFQM Excellence model and the ISO 9001:2000, Aarhus School of Business

26. National Institute of Standards and Technology (NIST) (2005), Criteria for Performance Excellence 2005, US Department of Commerce, Gaithersburg, MD.

27. Osseo-Assare, A., Longbottom, D. and Murphy, W. (2005), "Leadership best practices for sustaining quality in UK higher education from the perspective of the EFQM excellence model”, Quality Assurance in Education, Vol. 13 No. 2, pp. 148-70.

28. Sadiq-Sohail, M. and Shaikh, N.M. (2004), "Quest for excellence in business education: a study of student impression of service quality”, The International Journal of Educational Management, Vol. 18 No. 1, pp. 58-95.

29. Sampaio, P., Saraiva, P. and Monteiro, A. (2012), “A comparison and usage overview of business excellence models”, The TQM Journal, Vol. 24 No. 2, pp. 181-200.

30. Sharma, A.K. and Talwar, B. (2007), "Evolution of 'universal business excellence model' incorporating vedic philosophy”, Measuring Business Excellence, Vol. 11 No. 3, pp. 4-20. 
31. Talwar, B. (2011), "Business excellence models and the path ahead", The TQM Journal, Vol. 23 No. 1, pp. 21-35.

32. Watson, P (2000) 'Applying the European Foundation for Quality Management (EFQM) Model', Journal of the Association of Building Engineers, Vol 75 (4), pp 18-20. 